DOI https://doi.org/10.18551/rjoas.2017-11.21

\title{
OPEN INNOVATION AS A BUILDING BLOCK FOR SMALL MEDIUM ENTERPRISE HIGH-TECH IN «INTERNET OF THINGS» ERA: CASE OF THE INDONESIA
}

\author{
Hendrawan Muhammad Rosyihan* \\ Library and Information Science Program, University of Brawijaya, Indonesia \\ Bafadhal Aniesa Samira \\ Business Administration Science Program, University of Brawijaya, Indonesia \\ *E-mail: mrhendrawan@ub.ac.id
}

\begin{abstract}
Startup technopreneuship is a form of Small Medium Enterprise (SME) in Indonesia that has been able to implement an open innovation. This study aims to evaluate the application of open innovation in the SME based startup technopreneur. Futhermore, this research also analyzing the antecedent variables that drive open innovation such as the entrepreneurial orientation, organizational characteristics and environmental characteristics, then the implications on improvement SME performance innovation. This study used mixed method, with 37 startup technopreneur companies in Malang City, East Java Province, Indonesia as a respondent. Results of the study found that high tech SMEs, especially the startup technopreneur, are more prospective in applying open innovation compared to other types of SMEs in developing countries. In addition, this study shows that the entrepreneurial orientation, organizational characteristics and environmental characteristics has an important role to drive open innovation which will further improve the improvement SME performance innovation.
\end{abstract}

\section{KEY WORDS}

Internet of things, open innovation, SMEs high-tech, Indonesia.

Over the past few years, a new paradigm called Internet of Things (IoT) has become a buzzwords in the academic and industrial world. The belief that massive advances in microelectronics, wireless communications and information technology have been witnessed in recent years will continue in the future underlie the emergence of the loT revolution.

IoT is an illustration of where the virtual world through the internet is connected extensively to every-day-life objects in the real world (Raiwani, 2013; Palma et al. 2014; Samani et al., 2015). The physical object is transformed into a smart object, no longer disconnected from the virtual world, can be remotely controlled and can act as a medium of physical access to internet services in various domains such as home automation, fleet telematics, digital library, record management, e-government and smart city.

IoT is an open and comprehensive network of smart objects that have the capacity to operate automatically, share information, data and resources, reacting and acting in the face of environmental situations and changes (Madakam et al, 2015). IoT enables interoperability between human-to-human, human-to-things and even things-to-things in everyday life. This will then form the interconnection between objects to create an integrated ecosystem. IoT is ground zero for a new phase of global transformation supported by innovation technology, generating significant economic opportunities and shaping new industries.

According to the results of research from the United Nations Development Program (UNDP) (2001) in the Technological Achievement Index, Indonesia ranks 56th out of 67 countries. Therefore, Indonesia is expected to continue to innovate and produce a variety of intelligent products so that in the future Indonesia is expected to have competitive competitiveness and comparative with other countries in terms of technology.

As the development of internet in Indonesia is getting cheaper and easier, more and more people use internet media for various things, one of them entrepreneurship (Reuber 
and Fischer, 2011; Berisha-Shaqiri, 2015). Now many entrepreneurs who run internet-based business, technology and information or called technopreneur. This term is a combination of technology and entrepreneurs that are usually given to entrepreneurs who are technically literate, creative, innovative, and dynamic (Okorie et al., 2014; Rosly et al., 2015; SerokaStolka and Tomski, 2015).

Technopreneur is a driver of high-tech Small and Medium Enterprises (SMEs) sector in Indonesia which is expected to be responsive to take the opportunity to create and participate in the integrated ecosystem, so that IT-based creative industry will get a chance to further develop. Technopreneur is a part of entrepreneurship that will play a strategic role for the rotation and acceleration of the Indonesian economy in the future. Continuous technological developments lead to intense competition among business managers applying technology as the driving force of their business.

The technopreneur who is generally dominated by young people pioneered the business or internet-based company so called startup company. Now, the number of startup companies in Indonesia more and more and offer various products or services to consumers via the internet such as Freelancer.com, Tiket.com, and others.

Although it can be categorized into SMEs, the main feature of startup companies is to use information technology to build networks that support the flow of ideas and information both into and out of organizational boundaries in the loT era. The presence of IoT will facilitate the coordination and sharing of knowledge at low cost that can cross the boundaries of the organization and thus support the open innovation effort.

De Vrande et al. (2009) has developed a broad classification of open innovation motives specific to SMEs. They emphasize that SMEs should engage in an open innovation process for several reasons, among others, to improve product development and integrate new technologies, to gain external knowledge, to manage costs efficiently, to keep up with market developments, to optimally use employee skills and ideas, to improve employee motivation and commitment.

Researching open innovation practices on SMEs, especially high-tech SMEs is an important thing to do in order to improve the performance of technopreneur as a new industry sector. Open innovation has so far been studied primarily in high-tech and multinational companies. However, de Vrande (2009) has developed a special model used to measure open innovation practices on SMEs conducted in developed countries. This study aims to test the model de Vrande (2009) in the perspective of high-tech SMEs in Malang City, East Java Province, Indonesia which is a developing country. This study aims to examine the practice of open innovation by analyzing the factors of internal organization such as organizational characteristics, individual factors managers such as entrepreneurial orientation and external factors that are environmental characteristics that influence the practice of open innovation which then expected to affect the performance of SMEs innovation.

The first section of this article explains the background and the novelty of this study. The next section describes the review of the literature regarding open innovation and open innovation in high-tech SMEs based on startup technopreneur as well as theoretical and empirical basis supporting this research model. The third section discusses the research methodology. The fourth section presents the empirical results and discussion and the last one presents conclusions, limitations, and suggestions for further research.

\section{LITERATURE REVIEW}

Open Innovation. The concept of open innovation was first introduced by Chesbrough (2003) and has received extensive attention from researchers. Open innovation has become a new paradigm in innovation management which has changed the concept of closed innovation long developed in various companies. Closed innovation model is based on the view that the company should generate and develop ideas of their own to innovate and remain competitive (Chesbrough, 2003). Chesbrough (2003) states that in open innovation, 
companies can and should take advantage of their internal and external knowledge as well as expand the internal and external market to realize their potential for innovation.

Open Innovation in Startup Technopreneur SMEs. Van de Vrande et al. (2009) have initiated the first research on the application of open innovation in SMEs with a large sample in 605 SMEs in the Netherlands. The study has built a broad classification of the motif of open innovation for SMEs. Results of these studies confirm that SMEs pursuing open innovation, especially for market-related motives, as to meet customer demand, or maintain competitiveness with competitors. Furthermore, Lee et al. (2010) conduct a study on 817 SMEs in Korea and has developed a model of open innovation for SMEs by modifying the conventional open innovation models developed by Chesbrough (2003). Benefits for SMEs in applying open innovation, among others, for the distribution of risk, reduction of high cost structure, increasing knowledge base, and incorporation of internal resources and external companies (Tantau and Coras, 2013).

Organizational Characteristics. The organizational characteristic is the structure and the infrastructure equipment in the organization related to the preparation for the implementation of a management strategy ( $\mathrm{Li}, 2002)$. This organizational characteristic is divided into 2 (two) major groups, namely, 1) technological infrastructure, constituting equipment and systems that become instruments in cross-organizational communication and management activities and; 2) organizational infrastructure, are the factors that prepare the company to be ready to collaborate with the whole social system.

Environmental Characteristics. Environmental characteristics are environmental factors that affect the level of implementation of a corporate strategy where there are three major factors that are very influential include environmental uncertainty in business, competitive pressure to implement and readiness of business partners to collaborate (Li, 2002).

Innovation Performance. The concept of innovation performance refers to the organization's overall innovative ability to introduce new products in the marketplace, opening up new markets through the incorporation of a strategic orientation with behavior and innovation processes (Wang and Ahmed, 2004). Wang and Ahmed (2004) identifies five key areas that determine overall organizational innovation performance including product innovation performance, market innovation performance, process innovation performance, innovation behavior performance and innovation strategy performance.

Previous Research and Research Hypotheses. In the individual context, SME management in developing countries is required to have an entrepreneurial orientation to motivate SMEs in applying open innovation. This corresponds to a case study conducted by Lakovleva (2013) on SMEs operating in the oil sector in Norway, in which entrepreneurial orientation affects the implementation of open innovation, especially in small companies engaged in oil mining sector. Ju et al. (2013) conducted a study on 161 SMEs in Taiwan and found that there is significant influence between entrepreneurial orientation, open innovation, and corporate performance.

$H_{1}$ : Entrepreneurial orientation significantly influences the decisions of high tech SMEs in developing countries in implementing open innovation.

In the organizational context, SMEs are considered to be shaping specific organizational characteristics that support the company to implement open innovation. Finger and Stuki (2009) developed a model of factors influencing open innovation, which consists of external perspective of industries and companies as well as internal factors. Internal factors consist of strategies and goals of innovation, innovation management, and organizational characteristics. In addition, research conducted by De Mel et al. (2009) also found that organizational characteristics significantly influence innovation in SMEs.

$\mathrm{H}_{2}$ : Organizational characteristics significantly influence the decisions of high tech SMEs in developing countries in implementing open innovation.

In the environmental context, proper characteristics of environment can support SMEs to implement open innovation in and out the company. Abulrub and Lee (2012) conducted a study on 209 SMEs and 300 large enterprises in South Korea found that environmental factors have a significant effect on the application of open innovation. It is empirically supports the theory developed by Bingham (1976) stated in the adoption of innovation model 
by local government, organizational characteristics and environmental characteristics significantly influence adoption of innovation.

$\mathrm{H}_{3}$ : Environmental characteristics significantly influence the decisions of high tech SMEs in developing countries in implementing open innovation.

In the end, to be able to create and continuously improve the sustainability of the innovation performance, SMEs will require the application of open innovation as a whole. Research by Inauen and Wicki (2011) on 141 R \& D managers of companies listed on stock exchanges in Germany, Switzerland, and Austria, found that management strategies using the open outside-in innovation in the innovation process have a significant effect on the performance of the company's innovation. Furthermore, Parida et al. (2012) conducted a study on 252 high-tech SMEs conducting open innovation. Results of the study confirm that open innovation has a significant impact on improving innovation.

$\mathrm{H}_{4}$ : The application of open innovation can improve the innovation performance of hightech SMEs in developing countries.

\section{METHODS OF RESEARCH}

Sample and Data Collection. This exploratory research uses a quantitative research paradigm. Sample in this research is 37 startup companie in Malang City, Jawa Timur (East Java) Province, Indonesia. This study is a one-shot study where the data are collected simultaneously in one time period. Furthermore, this research uses survey method with questionnaire instrument. Data analysis methods used to prove the hypothesis proposed in this study using Generalized Structured Component Analysis (GSCA).

Table 1 - Frequency Distribution of Respondents by Company Type and Size

\begin{tabular}{|c|c|c|c|}
\hline \multirow{2}{*}{ Type of Startup Technopreneur } & \multicolumn{2}{|c|}{ Size of Companies } & \multirow{2}{*}{ Total } \\
\cline { 2 - 4 } & $\begin{array}{c}\text { Micro } \\
\text { (<10 employees })\end{array}$ & $\begin{array}{c}\text { Small } \\
(10-30 \text { employees })\end{array}$ & 16 \\
\hline Portal & 14 & 3 & 7 \\
\hline Application & 4 & 1 & 3 \\
\hline Game & 2 & 2 & 11 \\
\hline Marketplace Online & 9 & 8 & 37 \\
\hline Total & 29 & 3 & 16 \\
\hline
\end{tabular}

The respondents are distributed based on two main characteristics: the type of startup technopreneur and the size of the company based on the number of employees as shown in Table 1. The 37 SMEs are grouped by type of technology namely portal (16), applications (7), games (3) and online marketplace provider (11). In addition, based on the number of employees, the samples were classified into micro enterprises with number of employees less than 10 people (29) and a small company with a number of employees as many as 10 to 30 people (8).

\section{RESULTS AND DISCUSSION}

Moreover, Table 2 shows that in general the technology startup business most often implement open innovation is portal developer, while the type tend to be difficult to implement open innovation is games development. In the case of the exploitation of technology, portal developer enterprises are the most dominant in making venture and outward licensing of intellectual property. While in terms of employee engagement, corporate online marketplace indicates the most dominant practice among other types. In terms of technology exploration, portal companies are the most dominant to practice customer engagement, $R$ \& $D$ outsourcing, and inward license, whereas in terms of developing external network, providers of online marketplace arethe most dominant than the other types of companies.

Results of testing the hypothesis with a level at $5 \%$ indicate that the four hypotheses proposed are accepted and they demonstrate a significant effect. $\mathrm{H} 1$ calculation results show 
the value of t-statistic $>$ t-table $(3.98>1.97)$ and the path coefficient of 0.422 , so $\mathrm{HO}$ is rejected.

Table 2 - Open Innovation Practice Based on Technology Startup Types

\begin{tabular}{|c|c|c|c|c|}
\hline \multirow[b]{2}{*}{ Practices } & \multicolumn{4}{|c|}{ Types } \\
\hline & $\begin{array}{c}\text { Portal } \\
(n=16)(\%)\end{array}$ & $\begin{array}{c}\text { Applications } \\
(\mathrm{n}=7)(\%)\end{array}$ & $\begin{array}{c}\text { Games } \\
(n=3)(\%)\end{array}$ & $\begin{array}{c}\text { Marketplace Online } \\
(n=11)(\%)\end{array}$ \\
\hline \multicolumn{5}{|c|}{ Technology Exploitation } \\
\hline Ventura & $13.33 \%$ & $10.77 \%$ & $7.69 \%$ & $8.33 \%$ \\
\hline Outward Intellectual Property License & $13.33 \%$ & $10.77 \%$ & $12.82 \%$ & $5.56 \%$ \\
\hline Employee involvement & $11.67 \%$ & $7.69 \%$ & $15.38 \%$ & $27.78 \%$ \\
\hline \multicolumn{5}{|c|}{ Technology Exploration } \\
\hline Customer Engagement & $11.67 \%$ & $32.31 \%$ & $17.95 \%$ & $8.33 \%$ \\
\hline External network & $10.00 \%$ & $6.15 \%$ & $15.38 \%$ & $27.78 \%$ \\
\hline External participation & $11.67 \%$ & $9.23 \%$ & $7.69 \%$ & $8.33 \%$ \\
\hline Outsourcing R \& D & $15.00 \%$ & $12.31 \%$ & $15.38 \%$ & $5.56 \%$ \\
\hline Inward Intellectual Property License & $13.33 \%$ & $10.77 \%$ & $7.69 \%$ & $8.33 \%$ \\
\hline
\end{tabular}

This suggests that entrepreneurship orientation has a significant positive effect toward open innovation. These results support the results by Lakovleva (2013) and Ju et al. (2013). $\mathrm{H} 2$ calculation results show the value of $\mathrm{t}$ - statistic $>\mathrm{t}$-table $(3.8>1.97)$ and the path coefficient of 0.388 , so $\mathrm{HO}$ is rejected. This shows that organizational characteristics have a significant positive effect toward open innovation. These results support the research by Stuki and Finger (2009), Mortara and Minshall (2011), and Mel et al. (2009). H3 calculation results show the value of t-statistic > t-table $(7.45>1.97)$ and the path coefficient of 0.356 , so that $\mathrm{HO}$ is rejected. This suggests that environmental characteristics have a significant positive effect toward open innovation. These results support the research by Abulrub and Lee (2012) and the theoretical opinions of Bingham (1976). H4 calculation results show the value of t-statistic > t-table $(4.44>1.97)$ and the path coefficient of 0.352 , so $\mathrm{HO}$ is rejected. This suggests that open innovation has a significant positive effect toward performance innovation. These results support the results of empirical research conducted by Inauen and Wicki (2011), Parida et al. (2012), Mazzola et al. (2012) and Chen and Fan (2013).

\section{CONCLUSION}

This study shows that high tech SMEs, especially the startup technopreneur, are more prospective in applying open innovation compared to other types of SMEs in developing countries. Therefore, the application of open innovation is very suitable applied by technopreneur actors in face of loT era. This can be due to the characteristics of open innovation is very close to the era of information disclosure and knowledge as well as the involvement of various parties related to both internal and internal as required in the loT era. Hopefully in the future open innovation model can become building block technopreneur in face of loT era.

Furthermore, based on the results of data analysis in this study, it can be concluded that the high-tech SME sector in developing countries tend to be more open to innovation implementation extensively is small-sized companies compared to micro companies. These results support research by Teirlinck and Spithoven (2013), Michelino et al. (2014), and Hossain (2015), but contradictory with the research by van de Vrade et al. (2009). From these shortcomings, the researcher gives some suggestions for further research. Further studies must consider wider geographic coverage of developing countries, larger samples, and more specialized companies in Asia, America, Africa, Europe, and Australia to fill the limited literature on this sector. In addition, it open innovation research has been widely found on small and medium-sized companies, but a study involving with bigger sample of SMEs such as micro, small, and medium enterprises has not been conducted. 


\section{REFERENCES}

1. Abulrub, A.H. G., and Lee, J. (2012). Open innovation management: challenges and prospects. Procedia-Social and Behavioral Sciences, 41: 130-138.

2. Berisha-Shaqiri, Afërdita (2015), Impact of Information Technology and Internet in Businesses, Academic Journal of Business, Administration, Law and Social Sciences Vol 1 No 1, pp. 73-79.

3. Bingham RD. (1976). The Adoption of Innovation by Local Government. Lexington, Mass.: D.C. Heath.

4. Chen, Y. and Fan, B.Q. (2013). Relationship between open innovation capability of SMEs and innovation performance. Research and Development Management, 25: 24-35.

5. Chesbrough, H. (2003). The era of open innovation. MIT Sloan Management Review, 44(3): 35-41.

6. De Mel S., Mckenzie D., Woodruff C. (2009). Innovative firms or innovative owners? Determinants of innovation in micro, small, and medium enterprises, IZA Discussion Paper No. 3962. Institute for the Study of Labour, Bonn, Germany.

7. Finger, M., and Stucki, A. (2009). Open Innovation as an option for reacting to reform and crisis: what factors influence the adoption of open innovation. 2nd ISPIM Innovation Symposium New York: The International Journal of Innovation Management. 1530-1700.

8. Hossain, Mokter. (2015). A review of literature on open innovation in small and mediumsized enterprises. Journal of Global Entrepreneurship Research. 5(6): 1-12.

9. Inauen, M., and Schenker-Wicki, A. (2011). The impact of outside-in open innovation on innovation performance. European Journal of Innovation Management, 14(4): 496 - 520.

10. Ju, Pei-Hung, Deng-Neng Chen, Yu-Chun Yu, Hsiao-Lan Wei. (2013). Relationships among open innovation processes, entrepreneurial orientation, and organizational performance of smes: the moderating role of technological turbulence. Perspectives in Business Informatics Research, 158: 140-160.

11. Lakovleva, Tatiana. (2013). Open innovation at the root of entrepreneurial strategy. Technology Innovation Management Review, 17-22.

12. Lee, S., Park, G., Yoon, B., Park, J. (2010). Open innovation in SMEs-an intermediated network model. Research Policy, 39: 290-300.

13. Li, Suhong. (2002). An Integrated model for supply chain management practice, performance and competitive advantage. Doctoral Dissertation. Toledo, $\mathrm{OH}$ : University of Toledo.

14. Madakam, Somayya, Ramaswamy, R. and Tripathi, Siddarth. (2015), Internet of Things (IOT) : a Literature Review. Journal of Computer and Communications (3) :164:73.

15. Mazzola, E., Bruccoleri, M., and Perrone, G. (2012). The effect of inbound, outbound and coupled innovation on performance. International Journal of Innovation Management, 16 (6): 1-27.

16. Michelino, F., Lamberti, E., Cammarano, A. and Caputo, M. (2014). Measuring open innovation in the bio-pharmaceutical industry. Creativity and Innovation Management, 23(4): 1-25.

17. Mortara, L. and Minshall, T. (2011). How do multinational corporations implement Open Innovation? Technovation, 31(10-11): 586-597.

18. Okorie N. N, Kwa D.Y, Olusunle S.O.O. Akinyanmi A.O, Momoh I.M (2014), Technopreneurship: An Urgent Need In The Material World For Sustainability In Nigeria, European Scientific Journal October 2014 Edition Vol.10, No.30.

19. Palma, Daniel, Juan Enrique Agudo, Héctor Sánchez And Miguel Macías Macías (2014) "An Internet of Things Example: Classrooms Access Control Over Near Field Communication", Sensors 2014, 14, 6998-7012.

20. Parida, V, Westerberg, M, and Frishammar, J. (2012). Inbound open innovation activities in high-tech SMEs: the impact on innovation performance. Journal of Small Business Management, 50(2): 283-309.

21. Raiwani, Y.P (2013) "Internet Of Things: A New Paradigm", International Journal Of Scientific And Research Publications (Ijsrp), Volume 3, Issue 4, Pp. 1-4. 
22. Reuber, Rebecca and Fischer, Eileen. (2011), International entrepreneurship in internetenabled markets, Journal of Business Venturing, Volume 26, Issue 6, pp. 660-679.

23. Rosly, H.E., Junid, J., Lajin, N.F.M. and Rahim, H.L. (2015). The Relationship of Creativity And Technopreneurship Intention. International Academic Research Journal Of Social Science 1(1): 8-15.

24. Samani, Afshan, Hamada H. Ghenniwa, Abdulmutalib Wahaish. (2015), Privacy In Internet Of Things: A Model And Protection Framework, Procedia Computer Science 52, Pp. $606-613$.

25. Seroka-Stolka, Oksana and Piotr Tomski. (2015), Internet Social Media and International Entrepreneurial Intentions, Wei International Academic Conference Proceedings Vienna, Austria.

26. Tantau, A. and Coras, E. (2013). A risk mitigation model in sme's open innovation projects. Management \& Marketing, 8, 2(30): 303-328.

27. Teirlinck, $P$ and Spithoven, A. (2013). Research collaboration and R\&D outsourcing: Different R\&D personnel requirements in SMEs. Technovation, 33(4): 142-153.

28. The United Nations Development Program (UNDP). (2001), Human Development Report: Making New Technologies Work for Human Development. USA : OUP.

29. Van de Vrande, V, De Jong, JP, Vanhaverbeke, W, and De Rochemont, M. (2009). Open innovation in SMEs: trends, motives and management challenges. Technovation, 29(6): 423-437.

30. Wang, C. L. and Ahmed, P. K. (2004). The development and validation of the organisational innovativeness construct using confirmatory factor analysis. European Journal of Innovation Management, 7(4): 303-313. 